\title{
PENDAMPINGAN PENINGKATAN PENGETAHUAN PENGELOLAAN SUMBER DAYA AIR DI DESA BAYASA JAYA, KECAMATAN WAY KHILAU, KABUPATEN PESAWARAN
}

\author{
Zainal Abidin $^{1 *}$, Slamet Budi Yuwono², Dewi Lengkana ${ }^{3}$ \\ ${ }^{I}$ Jurusan Agribisnis, Fakultas Pertanian Universitas Lampung, \\ ${ }^{2}$ Jurusan Kehutanan, Fakultas Pertanian Universitas Lampung \\ ${ }^{3}$ Jurusan Pendidikan MIPA, FKIP, Universitas Lampung \\ Jl. Prof. Soemantri Brojonegoro 1, Bandar Lampung, 35145 \\ Penulis Korespodensi : zainal.abidin@fp.unila.ac.id
}

\begin{abstract}
Abstrak
Air bersih merupakan kebutuhan dasar masyarakat dan masyarakat desa umumnya memiliki akses yang kurang terhadap sumber daya air bersih. Kegiatan pendampingan ini dilaksanakan di Desa Bayas Jaya, Kecamatan Way Khilau, Kabupaten Pesawaran. Pengabdian ini bertujuan untuk meningkatkan pengetahuan tentang konservasi sumber daya air, kualitas air, dan pengelolaan sumber daya air. Langkah-langkah yang dilakukan meliputi: (1) assessment pengetahuan masyarakat tentang sumberday air, (2) penyuluhan pengelolaan sumber daya aair, dan (3) pendampingan penguatan tatakelol pengelolaan sumber daya air Pengabdian ini melibatkan 32 masyarakat yang mewakili 7 dusun, kelompok masyarakat, pemerintah desa, dan pihak yang berkepentingan seperti proyek BPDAS HL Way Seputih Way Sekampung melalui proyek CCCD serta KPHL Kabupaten Pesawaran. Masyarakat diberikan pelatihan tentang konservasi sumberday air, kualitasn air, dan pengelolaan sumberdaya air. Peserta pelatihan kemudian dilakukan pretest dan post-test kegiatan. Hasil pelatihan menunjukkan bahwa: (1) pengetahuan masyarakat tentang konservasi sumberday air, (2) pengetahuan masyarakat tentang kualitas air meningkat, dan (3) terdapat keiningan untuk membentuk kelompok pengelola sumber daya air.
\end{abstract}

Kata kunci: pendampingan, pengelolaan, konservasi sumber daya air

\section{Latar Belakang}

Menurut UU No 17 tahun 2019 tentang Sumber Daya Air, sumber daya air adalah air, sumber air, dan daya air yang terkandung di dalamnya. Sumber daya air adalah asset yang sangat penting untuk menjamin keberlanjutan seluruh makhluk hidup yang ada di dunia. Indonesia menjadikan akses terhadap sumber daya air, khususnya air bersih adalah salah satu dari sasaran strategis Sustainable Development Goals(SDGs). Akses air bersih dan kebersihan adalah sasaran ke 6 dari SDGs Indonesia (Bappenas, 2015). Oleh sebab itu, peningkatan pengelolaan sumber daya air sangat penting untuk dilakukan.

Desa Bayas Jaya terletak di Kabupaten Pesawaran, dengan jarak dari kota Bandar Lampung sekitar $50 \mathrm{~km}$ dan merupakan desa yang mengantungkan hidupnya pada sektor pertanian dengan komoditas utama adalah perkebunan (coklat). Desa Bayas Jaya memiliki 7 dusun yaitu
Dusun Bayas, Cong Kanan, Lebak Damar, Cirompang, Serkung Situk, Sinar Jaya, dan Serkung Tengos. Lokasi desa ini agak terisolasi dengan akses telekomunikasi yang kurang baik (Abidin, 2018).

Terdapat lebih kurang 986 kepala keluarga atau 3897 Jiwa yang hidup di Desa Bayas Jaya. Luas areal desa ini adalah 585 hektar dengan kepadatan 650 jiwa per $\mathrm{km}^{2}$ (Abidin, 2018). Berdasarkan UU No 56/PRP/1960 tentang Penetapan Luas Tanah Pertanian, kepadatan tersebut termasuk kategori sangat padat yaitu melebih 401 jiwa per $\mathrm{km}^{2}$. Dari gambaran di atas, Nampak bahwa Desa Bayas Jaya termasuk desa yang padat penduduk walauun lokasinya agak terisolasi.

Desa Bayas Jaya berbatasan langsung dengan Kawasan hutan lindung Register 21 yang dikelola oleh KPHL (Kesatuan Pengelolaan Hutan Lindung) Pesawaran. Dengan akses yang dekat, maka masyarakat desa ini memiliki 
ketergantungan yang tinggi pada sumber daya yang tersedia di kawasan hutan lindung, termasuk sumber daya air.

Berdasarkan observasi tim, sumber daya air yang yang digunakan oleh masyarakat Bayas Jaya berasal dari Hutan Lindung dan sungai Cong Kanan dan Cong Kiri. Dari Kawasan hutan lindung, sumber air dialirkan dengan pipa-pipa ke rumah masyarakat yang umumnya dilakukan secara individual/perorangan. Sumber air bersih mayoritas berasal dari pipa tersebut dan sumur rumah tangga serta sedikit dari kali Cong Kanan dan Cong Kiri.

Kondisi Kawasan hutan lindung Register 21 terus mengalami kerusakan akibat aktivitas pertanian yang dilakukan oleh masyarakat sekitar, baik masyarakat Bayas Jaya, maupun desa lain di sekitar. Kerusakan tersebut mengancam kondisi serta fungsi sumber daya air yang ada di kawasan hutan lindung dan tentunya akan mengancam kehidupan masyarakat di sekitar, termasuk masyarakat Desa Bayas Jaya. Ciri dari kurang baiknya sumber daya air adalah terjadinya perbedaan kekeruahan saat musim dan kemarau dimana saat musim hujan air menjadi sangat keruh dan tidak layak konsumsi sementara saat kemarau debit air menurun waluapun airnya bening (Abidin, 2018). Kondisi tersebut sangat erat dengan kondisi sumber mata air yang digunakan. Bila sumber daya air baik, maka air saat musim kemarau dan musim hujan tidak jauh berbeda.

Seperti di banyak kasus lain tentang degradasi sumber daya hutan dan air, peran manusia adalah sentral di dalamnya. Kawasan sekitar hutan sering merupakan konsentrasi kemiskinan seperti sekitar hutan konservasi TNBBS dan hutan lindung register 21 seperti studi yang dilaporkan oleh Abidin (2018). Menurut data Kementerian Kehutanan (2006) yang dikutip oleh Qodriyatun, 2013), ada sekitar 12\% dari 219,9 juta penduduk Indonesia yang tinggal di dalam dan sekitar Kawasan hutan. Dari $12 \%$ tersebut, atau sekitar 48,8 juta jiwa, 25\% termasuk kategori miskin. Konsentrasi masyarakat miskin dengan ketiadaan lahan yang sering mendorong upaya perambahan Kawasan hutan dan juga termasuk perusakan sumber daya air. Di sisi lain, pengetahuan masyarakat tentang konservasi sumber daya air juga kurang sehingga kondisi hutan dan sumber daya air mengalami kerusakan. Sementara itu, penegakan hukum atas pelanggaran pada sumber daya air tidak konsisten dijalankan
Sementara aturan local untuk pelembagaan pengelolaan sumber daya air juga tidak dikembangkan. Hal tersebut mengarah pada the Tragedy of the Commons) (Hardin, 1968) yang pada intinya menarasikan bahwa self interest pada system kelembagaan yang lemah mendorong terjadinya kerusakan sumber daya alam milik bersama.

Mengingat bahwa sumber daya air berperan sangat penting dalam keberlanjutan kehidupan masyarakat di wilayah ini, maka upaya menjaga sumber-sumber daya air tersebut merupakan hal sangat penting. Beberapa tantangan yang saat ini dihadapi dalam menjaga sumber daya air di desa meliputi: (1) semakin luasnya areal yang digunakan untuk keperluan permukiman dan pertanian akibat bertambahnya penduduk di kawasan Bayas Jaya. (2) lemahnya penegakan hukum terhadap pelanggar/perusak hutan yang ada di hulu, sehingga terjadi penurunan kualitas lingkunan, (3) kurangnya koordinasi antarpihak dalam menjaga kawasan hutan dan sumber mata air, dan (4) tidak adanya control terhadap kualitas air bersih dari sisi biologi dan kimia sehingga terjamin kualitasnya untuk masyarakat. Masalah seperti itu juga menjadi sorotan oleh Asdak (2015).

Berdasarkan UU No. 6 tahun 2014 tentang Desa, desa adalah kesatuan masyarakat hukum yang memiliki batas wilayah yang berwenang untuk mengatur dan mengurus urusan pemerintahan, kepentingan masyarakat setempat berdasarkan prakarsa masyarakat, hak asal usul, dan atau hak tradisional yang diakui dan dihormati dalam sistem pemerintahan Negara Kesatuan Republik Indonesia. Untuk mendapatkan dukungan dan partisipasi yang kuat dari masyarakat terhadap pembangunan desa, maka masyarakat harus dilibatkan dalam proses pengambilan keputusan termasuk pada tahapan perencanaan pembangunan desa. Dengan demikian diharapkan akan timbul suatu rasa tanggung jawab bersama seluruh masyarakat desa terhadap pembangunan di desanya.

Dengan UU No 6/2014 tersebut, desa memiliki kewenangan untuk mengelola sumber daya yang dimilikinya untuk sebesar-besarnya kemakmuran rakyat desa. Salah satu sumber daya yang penting di desa adalah sumberday air. Hal ini sesuai dengan bunyi pasal 1 ayat 7 yang menyatakan bahwa "Peraturan Desa adalah peraturan perundangundangan yang ditetapkan oleh Kepala Desa setelah dibahas dan disepakati 
bersama Badan Permusyawaratan Desa" dan itu menjadi bagian dari kewenangan desa sesuai dengan pasal 19 ayat b yaitu kewenangan skala desa.

Namun untuk Desa Bayas Jaya, peranan desa tidak nampak dalam pengelolaan sumber daya air kecuali bahwa desa menugaskan ketua lingkungan setempat untuk menjadi pengelola air. Pemerintah desa juga belum membuat peraturan yang mengikat kepada masyarakat dan lembaga dalam menjamin keberlanjutan pengelolaan. Di sisi lain, kualitas air yang dihasilkan belum pernah dikaji dan masyarakat tidak memahami tentang indicator air yang sehat untuk konsumsi.

Pendekatan konservasi sumber daya alam selama ini mengandalkan pada metode yang konvensional yaitu pembinaan. Pembinaan adalah upaya pendidikan formal maupun non formal yang dilakukan secara sadar, berencana, terarah, teratur, dan bertanggung jawab dalam rangka memperkenalkan, menumbuhkan, membimbing, dan mengembangkan suatu dasar-dasar kepribadiannya seimbang, utuh dan selaras, pengetahuan dan keterampilan sesuai dengan bakat, kecenderungan/keinginan serta kemampuankemampuannya sebagai bekal, untuk selanjutnya atas perkasa sendiri menambah, meningkatkan dan mengembangkan dirinya, sesamanya maupun lingkungannya ke arah tercapainya martabat, mutu dan kemampuan manusiawi yang optimal dan pribadi yang mandiri (Simanjuntak dan Pasaribu, 1990).

Untuk pemerintah, pembinaan seringkali diartikan sebagai pendekatan atas-bawah (topdown). Walaupun secara konsep, pembinaan yang baik adalah harus bersifat interaktif, dalam implementasi, pembinaan diterjemahkan sebagai kegiatan perintah antara yang membina terhadap yang dibina. Ada perbedaan dari sisi kesetaraan antara "pembina" dan yang "dibina" atau berbentuk hierarkis atas bawah. Akibatnya, hasil dari pendekatan tersebut kurang memberi pengalaman pembelajaran yang memadai dari sisi yang dibina.

Oleh sebab itu, pendekatan pembinaan perlu direrientasikan pada pendekatan yang memberikan pengalaman belajar (lesson learned) kepada peserta/partisipan. Pendekatan yang dimaksud dikenal dengan kegiatan pendampingan (assistantship). Dalam pengembangan masyarakat, pendampingan merupakan salah satu teknik yang sangat popular.
Pendampingan adalah pekerjaan yang dilakukan oleh pendamping masyarakat dalam berbagai kegiatan program dalam rangka memenuhi keutuhan tertentu masyarakat. Pendampingan diperlukan karena adanya keterbatasn yang dimiliki oleh masyarakat dalam menyelesaikan persoalannya dan untuk itu dibutuhkan pendamping atau fasilitator. Fungsi fasilitator adalah memotivasi, menggerakkan, menjadi bagian, mendengar masukan, mencari solusi, maupun menggali sumber daya (Sumodiningrat, 2000). Kelebihan dari pendekatan pendampingan adalah antara sasaran (masyarakat) dengan pendamping terjadi interaksi yang intensif dalam memecahkan sebuah persoalan.

Sementara itu, Karsidi (2007) menjelaskan satu prinsip pendampingan untuk pemberdayaan masyarakat adalah pengakuan akan pengalaman dan pengetahuan lokal masyarakat.

Unsur penting dari pendampingan adalah adanya partisipasi masyarakat (Galo dan Destriana, 2018) dalam meningkatkan efektivitas pemberdayaan masyarakat untuk mencapai kemandirian.

Dari uraian di atas, maka pendampingan dalam kegiatan pengabdian kepada masyarakat bertujuan untuk:

1. Meningkatkan pengetahuan masyarakat tentang konservasi sumber daya air'

2. Meningkatkan pengetahuan masyarakat tentang kualitas sumber daya air

Meningkatkan pengetahuan masyarakat tentang pengelolaan sumber daya air

\section{Bahan dan Metoda Pelaksanaan}

\section{A. Bahan yang digunakan}

Bahan yang digunakan untuk pengabdian ini adalah: (1) instrument penilaian dengan menggunakan daftar pertanyaan (kuesioner). Instrumen ini digunakan saat need assessment dan pre-test dan post test dari isi ceramah dan diskusi pengabdian kepada masyarakat

Dalam rangka mengetahui tingkat keamanan air bersih yang dikonsumsi/digunakan oleh masyarakat, kegiatan pengabdian melakukan pengambilan sampel air dari 3 titik sumber air bersih rumah tangga, Kemudian, sampel air dianalisis dengan beberapa parameter air bersih sesuai dengan pedoman Peraturan Menteri Kesehatan No. 492 tahun 2010 tentang Persyaratan Kualitas Air Minum dan PP 82/2001 tentang 
Pengelolaan Kualitas Air dan Pengendalian Pencemaran Air untuk Katergori Air Baku Minum. Sampel air diuji di Laboratorium Penguji dan Kalibrasi, Balai Riset dan Standardisasi Industri, Bandar Lampung. Ada 3 sampel yang diuji yaitu 2 sampel rumah tangga dan 1 sampel dari sungai Vong Kanan.

Parameter yang diuji adalah sebagai berikut: 1. Kesadahan 2. Padatan Terlarut total (TDS) 3. Padatan Tersuspensi Total (TSS) 4. Besi (Fe) 5. NH2-N 4. Posphate (PO4) Sampel air diinalisis di Laboratorium Inovasi Terpadu Universitas Lampung.

\section{B. Metode Pengabdian}

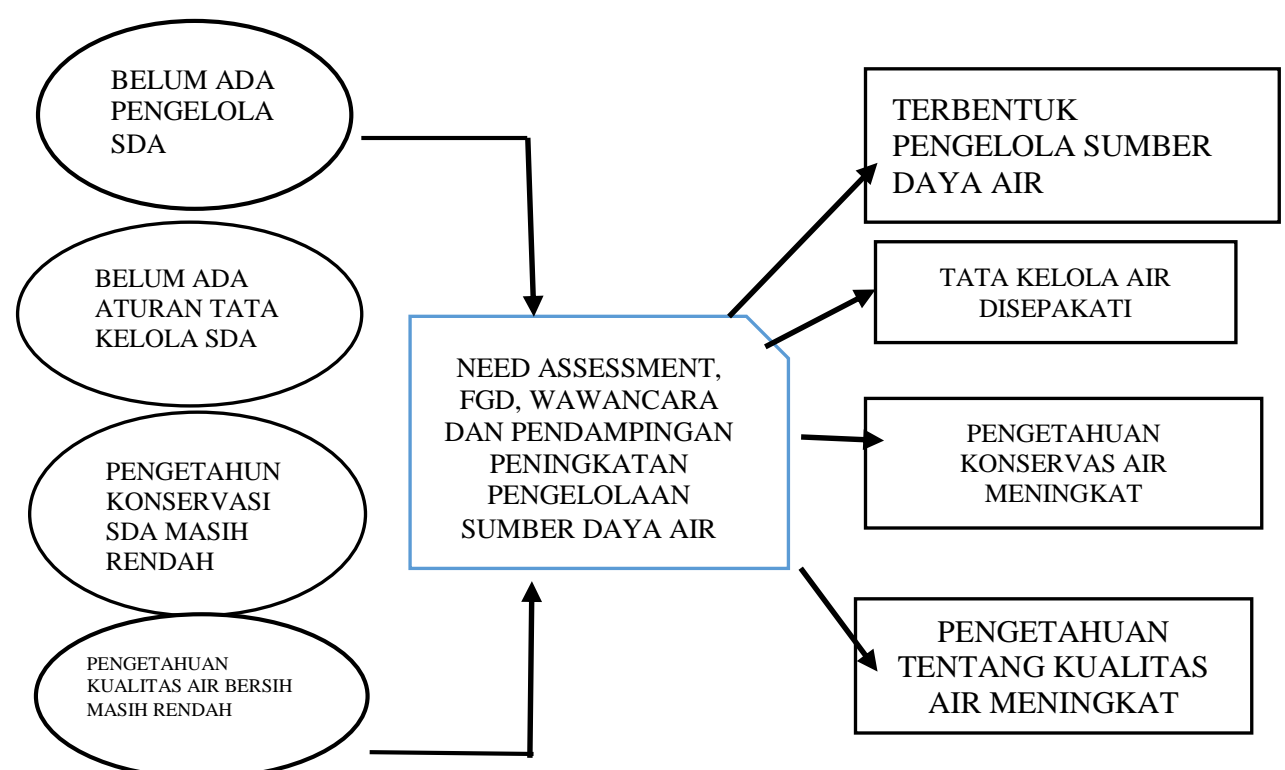

Gambar 1. Kerangka kerja pengabdian kepada masyarakat tentang Penguatan Pengelolaan Sumber daya air di Desa Bayas Jaya, Kecamatan Way Khilau, Kabupaten

\section{Pengumpulan data dan analisis hasil}

Jenis data yang dikumpulkan meliputi data perimer yang dilakukan melalui wawancara langsung. Data primer terkait dnegan identitas masyarakat dan dilakukan sebanyak 2 kali yaitu sebelum ceramah dan setelah ceramah, atau dikenal dalam evaluasi sebagai metode pre-test dan post test. Metode pre-test dan post test juga dilakukan oleh Yulianti, dkk (2019 dalam kegiatan pengabdian di Desa Sukajaya, Kecamatan Teluk Pandand, Kabupaten Pesawaran.Kuesioner yang diberikan bersifat: (1) ringkas, (2) mudah dimengerti, dan (3) sesuai dengan materi ceramah pengabdian yang disampaikan. Isi infromasi yang
Pelaksanaan Pengabdian kepada masyarakat ini akan melalui beberapa tahapan kegiatan yang terkait satu sama lainnya, yaitu

1. Persiapan dengan melakukan need assessment tentang pengetahuan konservasi sumber daya air, kualitas air, dan kelembagaan pengelolaan air,

2. Analisis need assessment

3. Ceramah dan diskusi tentang konservasi sumber daya air, kualitas air, dan kelembagaan pengelolaan air

4. Analisis perubahan pengetahuan

Secara skematis, langkah-langkah kegiatan pengabdian kepada masyarakat disajikan pada Gambar 1 di bawah ini. 
tentang luasan Kawasan lindung pada Desa Bayas Jaya, aktivitas-aktivitas BPDAS HL dan KPHL pada tahun 2018.

Data kemudian dianalisis dengan metode tabulasi dan naratif untuk menmahami perubahan pengetahuan masyarakat tentang sumber daya air.

\section{Hasil dan Pembahasan}

A. Analisis Need Assessment

Needs assessment merupakan pengumpulan dan analisis informasi yang sistematis dalam rangka mengidentifikasi kebutuhan, kondisi, dan kapasitas masyarakat yang menjadi sasaran kegiatan (UNHCR, 2017). Menurut Watkins, et al. (2012), dalam needs assessment, kesenjangan antara yang diinginkan dengan yang terjadi merupakan isu sentral dari kebutuhan akan kajian needs assessment.

Need assessment dilakukan sebelum kegiatan pengabdian dilaksanakan dengan mewawancari 22 masyarakat peserta yang terdiri dari $41 \%$ perempuan dan 59\% laki-laki. Hasil dari analisis need assessment menyimpulkan bahwa:

1. Sebagian besar masyarakat $(90 \%)$ mengetahui tentang sumber mata air yang mereka gunakan untuk konsumsi rumah tangga

2. Mayoritas masyarakat (90\%) setuju tentang perlu konservasi sumberdaya air

Tabel 1. Mitra dan peranannya

\begin{tabular}{|c|c|c|}
\hline No & Mitra & Peran \\
\hline 1. & $\begin{array}{l}\text { Pemerintah Pekon/Desa Bayas } \\
\text { Jaya }\end{array}$ & $\begin{array}{l}\text { 1. Memfasilitasi pertemuan/ FGD/ pendampingan } \\
\text { 2. Menerima masukan tentang air bersih } \\
\text { 3. Memfasilitasi rapat dengan LMD untuk peraturan pengelolaan } \\
\text { sumber daya air }\end{array}$ \\
\hline 2 & KPHL Pesawaran & $\begin{array}{l}\text { 1. Membantu informasi dan data tentang potensi sumber daya air } \\
\text { 2. Membantu memformulasikan kesepakatan peraturan } \\
\text { pengelolaan sumber daya air }\end{array}$ \\
\hline 3 & Kelompok Tani Hutan & $\begin{array}{l}\text { Memfasilitasi dan aktif berpetan dalam pertemuan dengan anggota } \\
\text { kelompok tani hutan yang memiliki potensi sumber daya air }\end{array}$ \\
\hline 4 & $\begin{array}{l}\text { BPDAS HL Way Seputih } \\
\text { Sekampung via proyek CCCD }\end{array}$ & $\begin{array}{l}\text { 1. Membantu data dan informasi tentang persoalan sumber daya } \\
\text { air di DAS Way Khilau } \\
\text { 2. Menjadi pendamping setelah kegiatan pengabdian selesai } \\
\text { 3. Memfasilitasi pertemuan need assessment dan pendampingan }\end{array}$ \\
\hline
\end{tabular}

\section{Perubahan Pengetahuan Paska Pelatihan}

Pelatihan tentang pengelolaan sumber daya air oleh tim. Pelatihan meliputi tiga isu: (1) konservasi sumber daya air, (2) kaualitas air, dan (3) kelembagaan pengelolaan sumberdaya air. Evaluasi terhadap perubahan pengetahuan peserta dilakukan dengan membantingkan antara pengetahuan sebelum dan sesudah kegiatan dengan metode pre-test and post-test.
3. Mayoritas masyarakat $(95 \%)$ masyarakat belum mengetahui cara menentukan kualitas air

4. Mayoritas masayrakat $(90 \%)$ belum pernah mendapatkan pelatihan pengelolaan sumberdaya air

5. Mayoritas masyarakat (95\%) menganggap perlu dilakukan pelatihan tentang sumber daya air

6. Mayoritas masyarakat (95\%) menganggap perlu adanya peraturan desa tentang pengelolaan sumber daya air.

Hasil di atas menunjukkan bahwa kegiatan pendampingan pengelolaan sumber daya air dibutuhkan oleh masyarakat. Hal tersebut sesuai dengan ekspektasi kegiatan pengabdian yang telah disusun sebelumnya. Dengan demikian, rencana kegiatan pengabdian dapat dilanjutkan.

\section{B. Keterlibatan mitra}

Kegiatan pengabdian kepada masyarakat ini akan melibatkan (a) KPHL Kabupaten Pesawaran, (b) Proyek CCCD melalui BPDAS HL, dan Pemerintah Desa Bayas Jaya, dan 1 kelompok tani hutan. Peran masing-masing tersaji pada Tabel 1 berikut ini. 
terendah adalah 5 tahun dan tertinggi adalah 13 tahun.

3. Tanggungan keluarga rata-rata adalah 4 orang dengan anggota keluarga terendah 1 orang dan tertinggi adalah 7 orang.

4. Mayoritas peserta tidak terkait dengan kelompok, karena hanya $27 \%$ peserta yang menjadi anggota kelompok seperti kelompok hutan, kelompok wanita tani, dan kelompok tani biasa.

Pengetahuan tentang konservasi sumberday air

Evaluasi perubahan pengetahui dilaksanakan setelah penyampaian materi konservasi sumberdaya air disampaikan oleh narasumber. Peserta ditanyakan secara ringkas pengetahuan tentang konservasi sumberdaya air.

Hasil perubahan sebelum dan sesudah pelatihan tentang materi konservasi sumberdaya air disajikan berikut ini.

Tabel 2 . Perubahan pengetahuan masyarakat tentang konservasi sumberdaya air sebelum dan sesudah pelatihan (\%)

\begin{tabular}{lccc}
\hline Keadaan & \multicolumn{2}{c}{ Pengeatahuan } & Jumlah \\
\cline { 2 - 3 } & Tdk tahu & Tahu & \\
\hline Sebelum & 91 & 9 & 100 \\
Sesudah & 52 & 48 & 100 \\
Perubahan & -39 & +39 & \\
\hline
\end{tabular}

Sumber: data primer diolah

Hasil tabulasi di atas, menunjukkan terjadi perubahan pengetahuan peserta terkait konservasi sumberdaya air sebelum dan setelah kegiatan penyampaian materi. Namun demikian, perubahan tersebut tidak terlalu tinggi yaitu hanya meningkat sebesar 39\% dari sebelumnya 9\% menjadi $48 \%$. Rendahnya peningkatan pengetahuan aspek konservasi sumberdaya air diduga karena faktorfaktor: (1) ruang pelatihan yang kurang memadai, (2) kelengkapan penerangan ruang belajar kurang baik, dan (3) materi pelatihan yang masih sukar dimengerti oleh sebagian peserta.

Dari sisi materi, bagian yang mudah dicerna oleh peserta meliputi: (1) aspek teknis konservasi sumberdaya air seperti: melakukan penanaman pada areal sumberdaya air, menentukan jenis tanaman yang cocok untuk perlindungan sumberdaya air,, (2) aspek lokasi penanaman yang baik untuk melindungai sumberdaya air. Aspek yang sulit dipahami oleh peserta tentang konservasi sumberdaya air adalah: (1) aspek penghitungan debit air, dan (2) aspek memilih tanaman yang unggul untuk konservasi sumberdaya air.

\section{Pengetahuan tentang kualitas air}

Kualitas air didefinisikan sebagai kondisi yang terkandung dalam air baik kandungan kimia, fisika, dan biologi serta kondisi warna air. Hal ini merujuk pada Peraturan Pemerintah No 82/2001 tentang kualitas air dan Pengendalian Pencemaran Air untuk Kategori Air Baku minimimum.

Air yang baik apabila air tersebut tidak berwarna, tidak berbau, dan berasa, dengan $\mathrm{PH}$ sekitar 7, Beberapa indicator lain yang penting adalah tentang Kesadahan, Padatan Terlarut, Padatan Tersuspensi, Kandungan Besi dan Fosfat. Yang paling utama dan secara visual nampak dan mudah diamati adalah tentang warna air harus bening, tidak ada bau, dan rasanya netral.

Mengingat bahwa kualitas air berhunugan dengan kesehatan masyarakat dan lebih-lebih balita, maka masyarakat perlu mengetahui cara menjaga kualitas air agar memenuhi baku mutu yang dianjurkan oleh pemerintah.

Setelah diadakan pelatihan, tim melakukan wawancara dengan memberikan angket pemahaman mereka tentang kualitas air, khususnya aspek fisik kualitas air Hal ini mengingat secara fisik kualitas air lebih mudah dilakukan karena menyangkut aspek warna, rasa, dan bau. Hasilnya tersaji pada tabel di bawah ini.

Tabel 3. Perubahan pengetahuan kondisi kualitas

\begin{tabular}{lcc}
\multicolumn{3}{c}{ air pre-test dan post test (\%) } \\
\hline $\begin{array}{l}\text { Mengetahui } \\
\text { kualitas air }\end{array}$ & Tdk tahu & Tahu \\
\hline Pre test & 91 & 9 \\
Post test & 41 & 59 \\
\hline Perubahan & -50 & +50 \\
\hline
\end{tabular}

Sumber: data primer diolah, 2019

Dari tabel di atas, nampak ada perubahan pengetahuan peserta pelatihan tentang kualitas air bersih. Dari sekitar hanya 9\%, menjadi 59\% yang mengetahui kualitas air bersih. Hal yang dipahami tentang air bersih yang berkualitas adalah air yang tidak berbau, tidak bewarna, dan tidakbe rasa.

Sementara, terkait dengan kualitas air secara kimia, fisika, dan biologi, seluruh responden tidak mengetahui baik sebelum maupun sesudah pelatihan. Hal ini mengingat, istilah-istilah untuk indicator kimia, biologi, dan fisika adalah konsep yang susah untuk dicerna oleh peserta pelatihan. 


\section{Pengetahuan tentang Tata Kelola Sumber Daya Air}

Isu kelembagaan merupakan hal penting dalam sumberday aair. Kelembagaan adalah seperangkat kebiasaan, peraturan, norma yang digunakan oleh masyarakat dan dalam rangka memenuhi kebutuhan masyarakat. (Soemardjan dan Soemardi, 1964). Kendati demikian, konsep kelembagaan tersebut di atas tidak merupakan konsep universal karena istilah kelembagaan ini memiliki arti yang beragam.

Uphoff (1986) mendefinisikan kelembagaan sebagai tatanan norma-norma dan prilaku yang beralku pada periode tertentu dalam rangka memenuhi kebutuhan umum masyarakat. Tatanan tersebut mungkin saja tidak berlaku lagi pada waktu lainnya. Jadi, berdasarkan konsep Uphoff, kelembagaan adalah tataprilaku masyarakat termasuk tatanan norma untuk memenuhi kebutuhan masyarakat namun bersifat temporer, tergantung dari perubahan social yang terjaadi pada masyarakat.

Pemenang nobel ekonomi tahun 2010, Ostrom (1999) menjelaskan kelembagaan sebagai "aturan dan rambu-rambu sebagai panduan yang dipakai oleh para anggota suatu kelompok masyarakat untuk mengatur hubungan yang saling mengikat atau saling tergantung satu sama lain. Penataan institusi (institutional arrangements) dapat ditentukan oleh beberapa unsur: aturan operasional untuk pengaturan pemanfaatan sumber daya, aturan kolektif untuk menentukan, menegakan hukum atau aturan itu sendiri dan untuk merubah aturan operasional serta mengatur hubungan kewenangan organisasi”.

Dari konsep kelembagaan di atas, kegiatan pengabdian saat ini diarahkan untuk mengembangkan kelembagaan dari dua aspek yaitu:

1. Aspek organisasi sumber daya air

2. Aspek tata aturan pengelolaan sumberaya air

Dari aspek organisasi, bentuk organisasi yang dimungkinkan adalah organisasi kelompok pengelola sumber daya air. Organisasi berbentuk kelompok lebih dimungkinkan karena bentuknya lebih sederhana dan sesuai dengan kondisi masyarakat setempat.

Hasil wawancara dengan peserta pelatihan menunjukkan bahwa mayoritas peserta pelatihan menganggap perlu adanya organisasi yang mengatur sumber daya air, seperti tersaji pada
Gambar di bawah ini. Sebagian kecil yang menganggap tidak perlu, sementara ada juga yang belum memahami perlu tidaknya organisasi pengelola air bersih.

Hasil kegiatan pengabdian menyimpulkan bahwa ssetelah mengikuti pelatihan, mayoritas masyarakat menganggap perlu adanya kelompok pengelola sumberdaya air bersih. Hal ini seperti tersaji ppada Gamba 2 berikut ini.

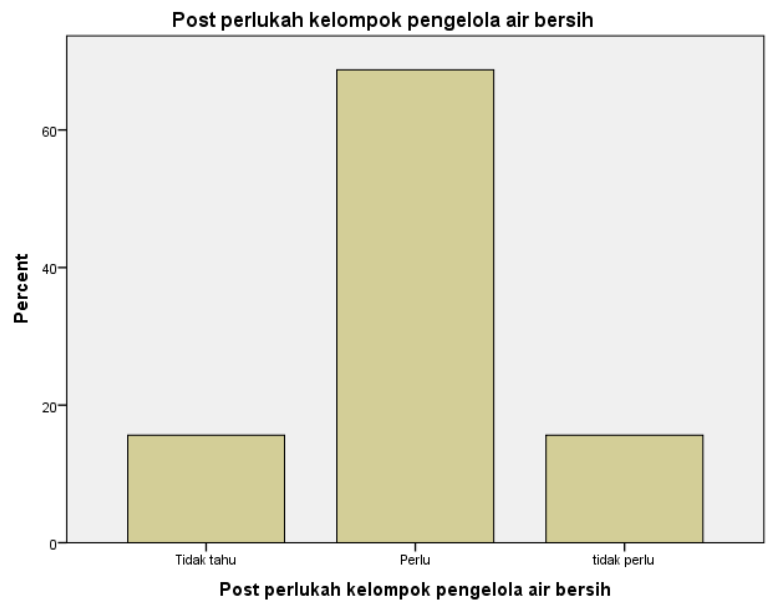

Gambar 2. Respon peserta atas perlunya kelompok pengelola sumberdaya air

\section{Faktor pendukung dan kendala}

Faktor pendukung kegiatan pengabdian ini adalah peran mitra khususnya proyek CCCD yang memiliki tujuan yang sama sehingga dapat membantu pelaksanaan pendampingan kegiatan lapang dan fasilitas pertemuan dengan masyarakat.

Sementara kendala yang dihadapi adalah Desa Bayas Jaya saat ini belum memiliki kepala desa definif sehingga keputusan tentang aturan tatakelola sumberdaya air belum dapat diputuskan, menunggu kepala desa definitive dilantik.

\section{Kesimpulan}

1. Pengetahuan masyarakat tentang konservasi sumberdaya air meningkat.

2. Pengetahuan masyarakat tentang kualitas air (indikator fisik) meningkat,

3. Terdapat keingingan yang kuat untuk membentuk kelompok pengelola air bersih.

\section{Ucapan Terima Kasih}

Tim penulis mengucapkan terima kasih kepada Dekan Fakultas Pertanian Universitas Lampung dan Lembaga Penelitian dan Pengabdian Kepada Masyarakat Universitas Lampung atas fasilitasi 
kegiatan Penguatan Pengelolaan Sumberdaya Air tahun akademik 2019.

\section{Daftar Pustaka}

Abidin, Z. (2018). Kajian Sosial Ekonomi dan Gender Di Sub-DAS Way Khilau, Sub-DAS Bulok, DAS Sekampung. Laporan Akhir: Deliverables 3. UNDP-Indonesia- Kementerian Lingkungan Hidup dan Kehutanan.

Asdak, Ch. (2015). Manajemen Konservasi Sumber Daya Air Terpadu: Pra-syarat Ketahanan Pangan. Makalah pada "Seminar Nasional Pengelolaan Sumber Daya Alam dan Lingkungan Hidup" diselenggarakan oleh Program Magister dan Doktor Ilmu Lingkungan, Program Pascasarjana Universitas Diponegoro, Semarang, 20 Agustus 2015.

Bappenas, (2015). Roadmaps of SDGs Indonesia: A Highlight. Jakarta.

Gulo, Y. dan N. Destriana. (2018) "Pemberdayaan Ekonomi Pedesaan Berbasis Partisipasi Warga Menuju Peningk Atan Dan Kemandirian Pengelolaan Ekonomi Di Desa Parakanlima, Cirinten, Lebak Banten". J. SAKAI SAMBAYAN Vol 2 No. 3, November 2018.

Hardin, G. 1968. "The Tragedy of The Commons". Science Vol. 162, Issue 3859, pp. 1243-1248, diunduh dari https://science.sciencemag.org/content/162/3859 $/ 1243$ pada tanggal 28 Agustus 2019.

Karsidi, R. (2007). Pemberdayaan Masyarakat Untuk Usaha Kecil Dan Mikro (Pengalaman Empiris di Wilayah Surakarta Jawa Tengah). Jurnal Penyuluhan Vol 3. No 2, September 2007

Ostrom, E. (1999). Self Governement and forest Resources. Occasional Paper No. 20. Center for Research on Agroforestry, Bogor
Qodriyatun, S.N., (2013). Pengentasan Kemiskinan Masyarakat Sekitar Hutan Konservasi: Studi Pemberdayaan Masyarakat Melalui Model Desa Konservasi. Pusat Pengkajian, Pengolahan Data dan Informasi (P3DI) Sekretariat Jenderal DPR Republik Indonesia. Jakarta.

Simanjuntak, B., dan I. L Pasaribu, (1990). Membina dan Mengembangkan Generasi Muda, Tarsito, Bandung: hlm. 84.

Soemardjan, S. dan S. Soemardi. (1964). Setangkai Bunga Sosiologi (Kumpulan Tulisan). Lembaga Penerbit Fakultas Ekonomi Universitas Indonesia, Jakarta.

Sumodiningrat, G., (2000). "Visi dan Misi pembangunan Pertanian Berbasis Pemberdayaan". IDEA, Yogyakarta.

UNHCR. (2017). Needs Assessment Handbook. New York.

Uphoff, N.. (1986). Local Institutional Development: An Analytical Sourcebook With Cases. Kumarian Press.

Watkins, R., M.W. Meiers., Y.L. Visser. (2012). A Guide to Assessing Needs: Essential Tools for Collecting Information, Making Decisions, and Achieving Development Results. World Bank. Washington.

Yulianti, D., A. Windah., M. Destalia. (2019). "Peningkatan Kapasitas Dan Pemberdayaan Kelompok Perempuan PKK (Pembinaan Kesejahteraan Keluarga) Melalui Penciptaan Usaha Strategis Berbasis Potensi Daerah (Studi Pada Kelompok Perempuan Pkk Desa Sukajaya Lempasing Kecamatan Teluk Pandan Kabupaten Pesawaran)". J. SAKAI SAMBAYAN. Vol 3 No. 2, Juli. 2019 